\title{
A NEW ERIOPHYID MITE FROM HYDRANGEA SP. IN BRAZIL, PARACAPHYLLA SETIFEMORATA, N.SP.
}

\author{
Carlos H.W. Flechtmann $^{1}$
}

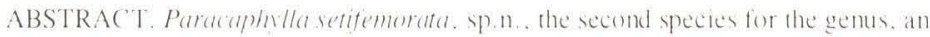

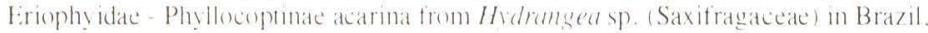
is described and figured

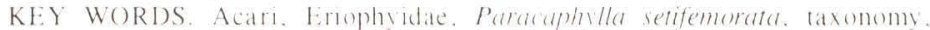
Hidranged
\end{abstract}

Mohanasi vDARAM ( 1983 ) erected the genus Paracaphvlla to accomodate a Phyllocoptine Eriophyid mite with divided featherclaws (empodia) and a broad median ridge and two troughs on either side on the histerosoma.

So far, according to AMRINE \& STASNy (1994) and AMRINE (personal communication) the genus remains monospecific, that is, restricted to the type species, P. streblae Mohanasundaram, 1983, a leaf vagrant on Streblus asper Lour. (Moraceae) in India.

A second species is herein described.

\section{Paracaphylla setifemorata, sp.n.}

Fig. 1

Diagnosis. Paracaphylla setifemorata, sp.n. differs from P. streblae in presenting femoral setae : each branch of the divided empodia with 3 rays $(6$ or more rays in $P$. streblae); prodorsal shield with admedian lines forming large cells (shield smooth in $P$. streblae) and female genital shield with anterior transverse and posterior longitudinal ridges (only anterior scorings in $P$. streblae).

Female: holotype and range: $n=10$. All measurements are reported in micrometers.

Elongate dorsoventrally flattened idiosoma 195.4 (191.9-230.6) long, 64.2 (60.0-72.2) wide. Gnathosoma 22.5 (19.4-23.8) long: basal setae $1.6(2.6-4.4)$ long; antapical setae prominent, 3.5 (3.5-4.4) long. Chelicerae 17.6 (16.7-18.5) long; oral stylets $11.0(10.6-12.3)$ long. Prodorsal shield 38.7 (37.0-41.2) long, 57.9 (51.9-66.9) wide. Admedian lines starting near anterior margin, complete to rear shield margin. forming a row of 1-1-2-2 large cells. Prodorsal shield tubercles away from rear shield margin, 24.6 (23.8-25.5) apart, dorsal selac pointing up and inwards, slightly to the rear, 4.4 (4.4.-4.8) long. Iegs with all normal setae

1) Departamente de Zoologia. Iniversidade de Säo Paulo. ESALQ. Caixa Postal 9. 13418-90() Piracicaha, Säo Paulo. Brasil. ( NPu Fellow. 

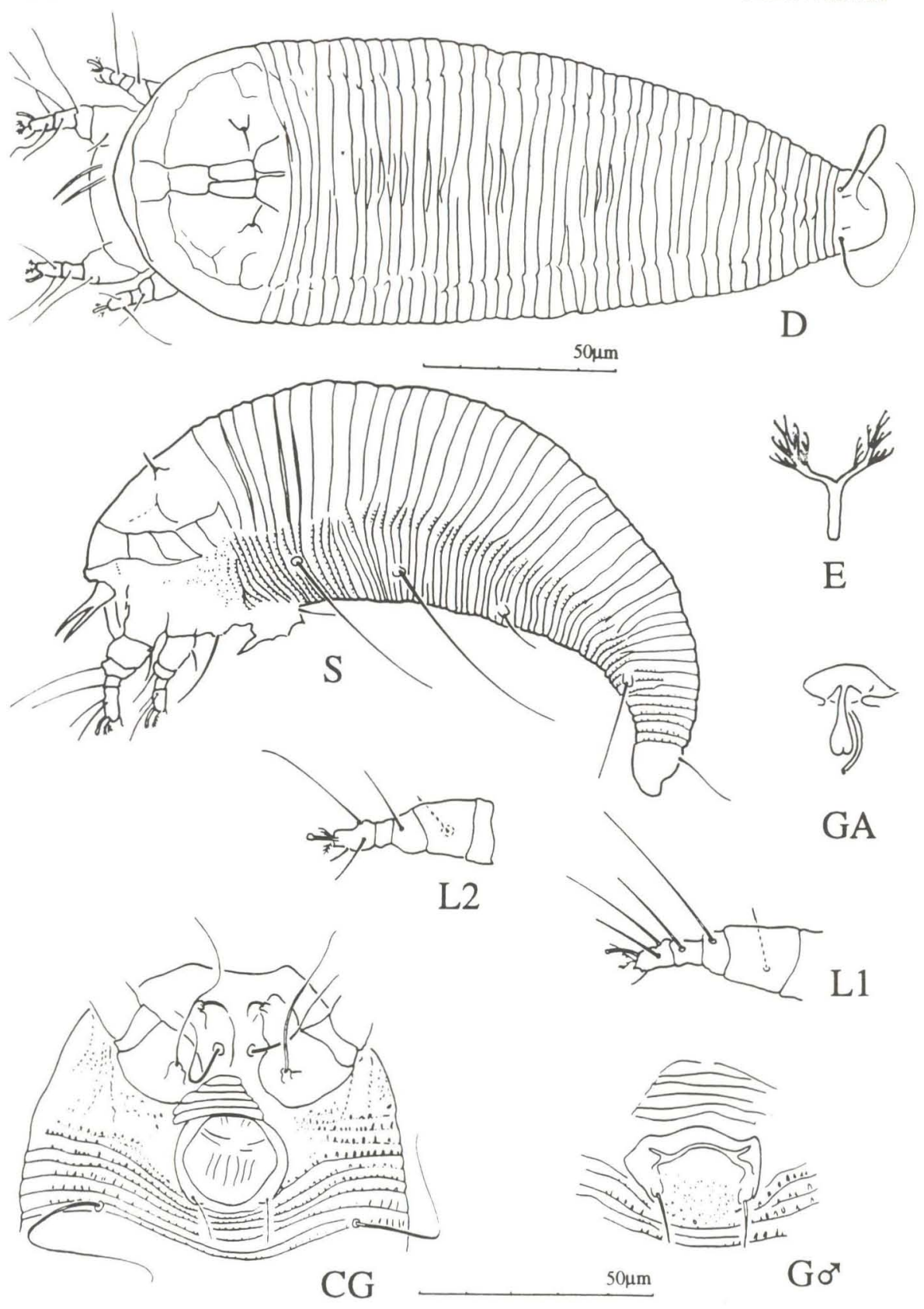

Fig. 1. Paracaphylla setifemorata, n.sp.. (D) Dorsal aspect; (S) lateral aspect; (CG) coxigenital area; (E) empodium (enlarged); (L1) leg I; (L2) leg II, of female; (Gơ) genital area of male; (GA) genital apodeme of male. 
present. Legs I, from trochanter base to tip of tarsus, excluding empodium and solenidium, $24.6(24.6-30.0)$ long; femora I 9.7(7.9-11.4) long, femoral setae 8.8 (6.2-8.8) long; genua I 4.4 (3.5-4.4) long, genu I setae 22.0 (22.0-26.4) long; tibiae I 4.4 (3.5-5.3) long, tibia I setae 17.6 (15.8-19.4) long; tarsi I 4.4 (4.4-7.0) long, solenidia $5.3(5.3-7.0)$ long, empodia 4.4 (4.4-5.3) long, fully divided, each branch with three pairs of rays; tarsi I dorsal setae 17.6 (16.7-20.2) long, lateral setae 14.1 (11.4-14.1) long and mesal setae 4.0 (3.5-4.4) long. Legs II 23.8 (22.9-25.5) long; femora II 7.0 (7.0-11.4) long, femoral setae 7.9 (6.2-7.9) long; genua II 3.5 (2.2-3.5) long, genu II setae 11.4 (10.6-14.1) long; tibiae II 3.5 (2.6-3.5) long; tarsi II 4.4 (4.0-6.2) long, solenidia 5.3 (5.3-7.0) long, empodia 4.4 (4.4-5.3) long, fully divided, each branch 3-rayed; tarsi II dorsal setae 17.6 (15.8-21.1) long, tarsi II lateral setae 6.2 (5.3-7.0) long, and mesal setae 4.4 (3.5-4.4) long. Venter: Sternal line 7.9 (7.9-8.8) long. Coxal setae I 10.6 (9.7-12.3) apart, 6.2 (4.4-6.2) long; coxal setae II 7.0 (5.3-7.0) apart, 16.7 (15.8-19.4) long; coxal setac III 23.8 (22.9-23.8) apart, 37.() (37.0-42.2) long. Coxigenital region with 5 (5-6) annuli, smooth, devoid of microtubercles. Epigynium 19.4(17.6-22.0) wide, 13.2 (13.2-15.0) long; anterior half of covertlap with two transversal, medially interrupted, lines or ridges; posterior half with 6 longitudinal lines or ridges. Genital setae 9.7 (8.8-10.6) long. Opisthosoma: dorsum with a broad ridge, narrowing posteriorly, with a trough on either side. Lateral setae 38.7 (34.3-49.3) long, on 7th (6th-8th) annulus. Ventral setae 1, 33.4 (30.8-35.2) apart, 52.8 (52.8-66.9) long, on annulus 21 (20-23); ventral setae 2 , 19.4 (16.7-19.4) apart, $10.6(9.7-14.1)$ long, on annulus 37 (35-41); ventral setae $3,24.6(23.8-25.5)$ apart, $22.0(22.0-33.4)$ long, on annulus 55 (52-59) or 7 (7-8) from rear. Total dorsal annuli 48 (46-52); total ventral annuli 62 (59-66). Caudal setae 40.5 (40.5-47.5) long; accessory setae minute, $1.8(0.9-1.8)$ long.

Male: smaller than female. Measurements of one male paratype.

Body 171.6 long, 52.8 wide. Basal seta on pedipalp 4.4 long; antapical seta 2.6 long. Chelicerae 14.1 long. Prodorsal shield as in female, 32.6 long, 49.3 wide. Tubercles 22.0 apart, setae 3.5 long. Leg I 23.8 long; femur I 7.9 long, femoral seta 7.0 long; genu I 3.5 long, genu I seta 20.2 long; tibia I 3.5 long, tibia I seta 12.3 long; tarsus I 5.3 long, solenidium 5.3 long, empodium 4.4 long, deeply divided, each branch 3-rayed; tarsus I dorsal seta 15.0 long, tarsus I lateral seta 11.4 long and mesal seta 3.5 long. Leg II 22.9 long; femur II 7.0 long, femur II seta 6.2 long; genu II 2.6 long, genu II seta 7.9 long; tibia II 2.6 long; tarsus II 5.3 long, solenidium 5.3 long, empodium 4.4 long, deeply divided, each branch 3-rayed; tarsus II dorsal seta 14.1 long, lateral seta 6.2 long and mesal seta 3.5 long. Venter: Sternal line 8.8 long. Coxal setae I 12.3 apart, 4.4 long; coxal seta II 5.3 apart, 15.0 long; coxal seta III 23.8 apart, 32.6 long. Coxigenital region with five smooth annuli. Genital shield 17.6 wide, 8.8 long, with dots. Genital setae 6.2 long. Opisthosoma: similar to female; lateral seta 30.8 long, on 7 th annulus; ventral seta 1,31.7 apart, 44.0 long, on annulus 15; ventral seta 2, 17.6 apart, 7.0 long, on annulus 31; ventral seta 3, 22.0 apart, 20.2 long, on annulus 47 or 7 th from rear. Total number of dorsal annuli 39, total ventral annuli 54. Caudal setae 31.7 long, accessory setae 1.8 long. 
Type material data: female holotype, 17 female paratypes, two male paratypes, on four microscopic preparations, from $H$ ydrangea sp. (Saxifragaceae). Parque Nacional do Itatiaia. Rio de Janeiro, 24 Dec. 1993, CHWF, in the collection of Department of Zoology, University of São Paulo - ESALQ (Piracicaba, São Paulo).

Relation to host: Underside leaf vagrants.

Etymology. The genus name Paracaphylla is derived from the genus Acaphlla Keifer, 1943. KEIFIR (1943) and MOHANASINDARAM (1983) made no reference to etymology. The most likely guess on its derivation is that it was composed of aca, from Acarus, mite, Latin, masculine, plus either phyllon, leaf, Greek, neuter and latinized as phylla, feminine, or phyllas, -ados, foliage, Greek, feminine, as Keifer collected the type species for his genus, A. steinwedeni Keifer, 1943 from leaves.

Since in compound words the final component, if a noun, determines the gender (BROwn 1956), Acaphylla, as well as Paracaphylla are then feminine.

The species designation setifemorata is composed of seti. from setifer, Latin, bearing bristles or setiferous, plus femorala from femur. femoris, Latin, femur, refering to the presence of a seta on femora I and II, one of the characters which distinguishes the new species from the type species.

ACKNOWLEDGEMENTS. The help of J.W. Amrme Jr. and T.A. Stanly of the West Virginia University. USA, with basic information on Enophy id axonomy is apprectated. as well ats of A. R. Monteiro of the Iniversity of Sào Paulo-ESAL.Q. with the Latin and Greek derivations.

\section{REFERENCES}

AMrine JR., J.W. \& T.A. STASNY.1994. Catalog of the Eriophyoidea (Acarina: Prostigmata) of the World. Michigan, Indira Publ. House, 798p.

Brown, R.W. 1956. Composition of Scientific Words. Baltimore, Publ. by the author, Reese Press, 882p.

Keifer, H.H. 1943. Eriophyid Studies XIII. Bull. Calif. Dept. Agric. 32 (3): $212-222$

Mohanasundaram, M. 1982 |1983|. New genera and species of Eriophyoidea (Acarina) from South India. Indian Jour. Acarol. 7 (2): 53-58. 